\title{
Chlorinediffuser sebagai metode menurunkan total coliform Wai Sauq bantaran Sungai Mandar
}

\author{
Patmaawati $^{1,}$ Sukmawati $^{2}$ \\ ${ }^{1,2}$ Program Studi S1 Kesehatan Masyarakat Universitas Al Asyariah Mandar, Polewali Mandar, \\ Sulawesi Barat. \\ E-mail: fatmawatidongky@gmail.com
}

\section{Chlorinediffuser As A Method Of Reducing The Total Number Of Wai Sauq Coliforms Along The Mandar River}

\begin{abstract}
The Polewali Mandar community partly relies on the Mandar River river to meet the need for clean water so that methods are needed to produce quality standards for proper consumption. This study aims to determine the effectiveness of the use of the chlorine diffuser method in reducing the total amount of coliform wai sauq which is carried out experimentally based on the application dosage of observation time in the control group and the treatment group. The analysis technique used is the results of comparative laboratory tests with the Minister of Health Regulation and the results of the Environmental Agency examination. The results of the examination of the physical parameters of the samples found that the total bacterial content of the coliform wai sauq mandar river was more than $1600 / 100 \mathrm{ml}$. After the addition of chlorine in the sample sauq with application time of 1 hour, the total coliform bacteria has decreased by $46 /$ $100 \mathrm{ml}$, this shows that it has met the required maximum standard levels. To improve the quality of wai sauq, it can be done by applying a simple appropriate technology, namely chlorine diffuser that is suitable with the environment of river water. The chlorine diffuer tool is expected to be able to help deal with the problem of clean water, especially the improvement of water quality in a bakeriological manner (disinfection), so that it can be utilized as a source of drinking water.
\end{abstract}

Keywords: Chlorine diffuser, Wai Sauq along river

\begin{abstract}
Abstrak
Masyarakat Polewali Mandar sebagian mengandalkan wai sauq untuk memenuhi kebutuhan air bersih sehingga diperlukan metode untuk menghasilkan baku mutu air layak konsumsi.. Alat chlorine diffuser diharapkan dapat membantu menangangani masalah air bersih sehingga kejadian diare tidak mengalami kenaikan setiap tahunnya terjadi di bantaran Sungai Mandar. Penelitian ini bertujuan untuk mengetahui efektifits penggunaan metode chlorine diffuser dalam menurunkan total coliform wai sauq yang dilakukan secara eksperimen berdasarkan pemberian dosis aplikasi waktu pengamatan pada kelompok kontrol dan kelompok perlakuan. Teknik analisis yang digunakan adalah hasil uji laboratorium perbandingan terhadap Peraturan Menteri Kesehatan Nomor 32 tahun 2017 dan rujukan pemeriksaan sebelumnya oleh Badan Lingkungan Hidup. Hasil penelitian menunjukkan bahwa kualitas wai sauq mengalami penurunan kualitas berdasarkan hasil pemeriksaan laboratorium yaitu pada pengamatan waktu kontak selama
\end{abstract}


1 jam jumlah bakteri total coliform mengalami penurunan. Untuk peningkatan kualitas wai sauq dapat dilakukan dengan menerapakan teknologi sederhana tepat guna yaitu chlorine diffuser yang sesuai dengan lingkungan perairan sungai..

Kata kunci: Chlorinediffuser, Wai Sauq bantaran Sungai Mandar

\section{PENDAHULUAN}

Air baku yang biasa digunakan dalam pengolahan air bersih sebagian besar berasal dari badan air atau sungai yang mengandung berbagai macam polutan. Proporsi pemakaian air kurang dari 20 liter perorang perhari di rumah tangga, antara tahun 2013 dengan tahun 2018 semakin berkurang, dari rata-rata nasional 20\% menjadi 5\% yang artinya akses terhadap air semakin meningkat dan untuk wilayah Provinsi Sulawesi Barat dengan air minum yang layak $60,66 \%$. ${ }^{(1)}$

Sungai Mandar sejatinya adalah batang air yang mengalir melewati ratusan pemukiman. Kebutuhan air bersih penduduk memang tak tergantung pada air yang dialirkan Perusahaan Air Minum disebabkan air yang dialirkan hampir tidak layak konsumsi karena asin, air Sungai Mandar yang diangkut dengan menggunaka jerigen di awal pagi yang diistilahkan wai sauq (wai artinya Air, Sauq berarti menimba), disebut wai sauq karena diambil dengan cara menggali lobang-lobang kecil di tepi sungai, setelah air dalam lobang di atas pasir sungai berdiameter $50 \mathrm{~cm}$ dan kedalaman $60 \mathrm{~cm}$ itu dinilai sudah bersih dan tidak keruh. Tradisi warga ini adalah bentuk upaya pelestarian leluhur etnis suku Mandar yang tidak merusak ekosistem air yang ada di Sungai Mandar. Sebagian warga yang bermukim di bantaran Sungai Mandar, masih meminum langsung air yang difilterisasi secara alami oleh warga. ${ }^{(2)}$

Permasalahan yang sering dijumpai bahwa kualitas air tanah maupun sungai yang digunakan masyarakat kurang memenuhi syarat sebagai air bersih/air minum yang sehat dan aman di konsumsi. Air minum mempunyai standar persyaratan tertentu yakni persyaratan fisik, kimiawi, dan bakteriologis. Air minum yang tidak memenuhi standar kualitas tersebut dapat menimbulkan gangguan kesehatan, disenfeksi merupakan mikroorganisme yang dapat menimbulkan penyakit termasuk bakeri dan protozoa.

Hasil Pemantauan yang dilakukan oleh Dinas Badan Lingkungan Hidup 
untuk parameter total coliform tahun 2018 yaitu $920 \mathrm{kol} / 100 \mathrm{ml}$ dan di tahun 2019 mengalami kenaikan yaitu lebih besar dari $1.600 \mathrm{kol} / 100 \mathrm{ml}$ sampel, hal ini menunjukkan bahwa Sungai Mandar mengalami penurunan kualitas, diantaranya karena banyaknya sampah plastik dan sampah rumah tangga hanyut di badan sungai. Lokasi tersebut juga digunakan warga mandi dan mencuci pakaian (termasuk kendaraan dan binatang peliharaan ${ }^{(3)}$

Coliform merupakan golongan mikroorganisme yang lazim digunakan sebagai indikator, dimana bakteri ini dapat menjadi sinyal untuk menentukan suatu sumber air telah terkontaminasi oleh patogen atau tidak. Air bersih yang sudah tercemar bakeri eschercia coli maupun total coliform yang melebihi persyaratan maka akan menyebabkan penyakit diare. Data tahunan kasus diare yang ada kecamatan Tinambung masih cukup tinggi yaitu sebesar 102 kasus atau $16 \%$ yang terjadi setiap tahunnya dan untuk Wilayah Kecamatan Limboro kasus kejadian diare dari bulan januari sampai dengan bulan maret 2019 sebanyak 155 orang penderita berdasarkan laporan tingkat kejadian 10 penyakit terbesar di Kabupaten Polewali Mandar. ${ }^{(4)}$
Masalah utama yang harus dihadapi dala pengelolaan air ialah semakin tingginya tingkat pencemaran air yang berasal dari limbah rumah tangga, sehingga upaya-upaya bar uterus dilakukan untuk mendapatkan sumber air, khususnya untuk pemenuhan akan air minum yang memenuhi persyaratan yang telah ditetapkan. ${ }^{(5)}$

Keterbatasan pengetahuan dan sumber daya masyarakat dalam memahami kualitas baku mutu air, menuntut adanya suatu solusi dan penyelesaian yang mudah diterapkan. Salah satu teknologi air bersih yang tepat guna adalah chlorinasi untuk membunuh kuman didalam air dengan mempergunakan senyawa klor. Klor banyak digunakan untuk menghasilkan air minum yang aman, baik untuk keperuan sanitasi dan desinfektan.

Penerapan teknologi pengelolaan air diharapkan dapat menyesuaikan dengan kondisi sumber air baku, kondisi sosial, budaya, ekonomi dan sumber daya manusia setempat. Salah satu metode yang banyak digunakan dalam proses pengolahan air sungai adalah penghilang bakteri total coliform menggunakan sistem klorinasi. Hal ini dengan pertimbangan bakteri total coliform mudah didesinfeksi oleh klorin, waktu kontak yang dibutuhkan 
sangat singkat, sehingga cocok untuk mengolah air permukaan dalam jumlah banyak dan berkelnjutan serta klorin mudah didapat dipasaran dengan harga yang murah.

Cara pembubuhan kaporit dapat dilakukan secara bertahap dengan menggunakan alat chlorine diffuser. Pembubuhan kaporit dengan cara menggunakan chlorine diffuser memiliki kelebihan yaitu kadar kaporit yang tercampur dalam air akan terurai secara perlahan, tidak menimbulkan bau dan dapat dengan mudah diterapkan oleh masyarakat umum.

Metode chlorine diffuser merupakan salah satu teknologi pengolahan air bersih yang tepat guna tersebut adalah chlorinasi dalam mencegah maupun menanggulangi pencemaran bakteri dengan indicator total coliform. Dampak dari cemaran baku mutu air yang disebabkan oleh bakteri total coliform berupa gangguan saluran pencernaan terutama diare sehingga metode chlorine diffuser mampu mengurangi cemaran bakteri dengan jumlah yang cukup tinggi dan mampu memperbaiki proses baku mutu air dari cemaran. ${ }^{(6)}$
Tradisi masyarakat menggali sumber air dari sungai untuk diminum langsung setelah difilterasi secara alami serta kejadian penyakit infeksi diare setiap tahunnya maka urgensi masalah yang menjadi perhatian yang diteliri apakah metode chlorine diffuser mampu menurunkan pencemaran air oleh bakteri total coliform dengan focus pada tujuan yang ingin dicapai untuk mengetahui efektivitas penggunaan metode chlorine diffuse dalam menurunkan bakteri total coliform pada wai sauq bantaran Sungai Mandar. (7)

\section{BAHAN DAN METODE}

Alat penelitian yang digunakan dalam penelitian ini dalam pembuatan chlorine diffuser adalah pipa PVC, Dop PVC, lem pipa, penggaris, mata gergaji besi, gergaji besi, amplas, paku pembakar bunsen, tabung reaksi tabung reaksi dan pinset steril. Bahan yang digunakan dalam penelitian adalah Air baku wai sauq bantaran Sungai Mandar, bubuk kaporit, pasir kasar yang bersih dan kering, secara rinci pada gambar tabel dibawah ini: 
Gambar 1.1. Kerangka chlorine diffuse

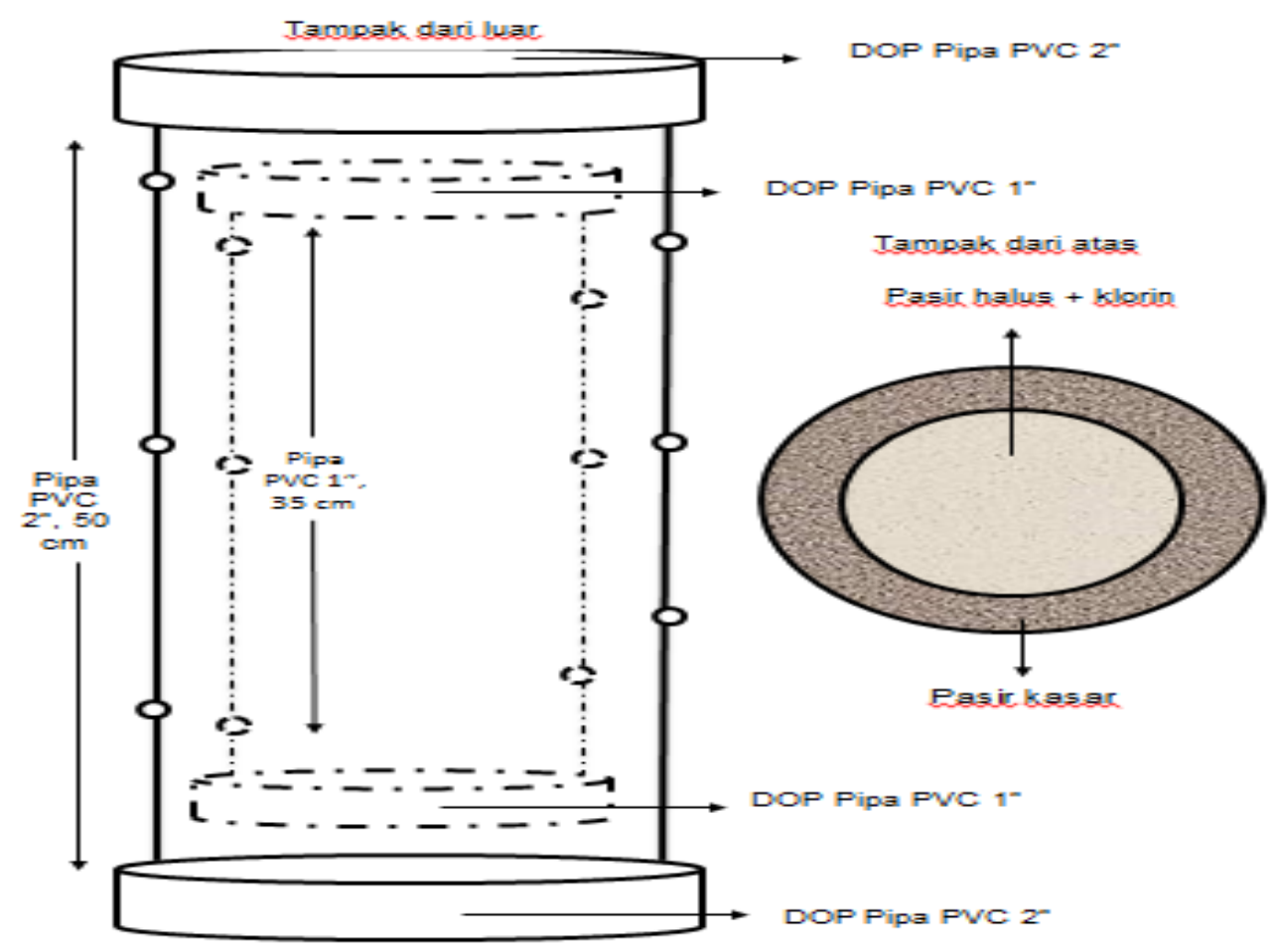

Pembuatan rancang bangun alat ini di laksanakan dii balai teknik kesehatan lingkungan dan pengendalian penyakit Kelas 1 Makaasar yang digunakan sebagai desinfeksi wai sauq yang relative sederhana, mudah dibuat dan menggunakan bahan dasar lokal. Metode alat chlorine diffuser dapat membunuh atau meminimalkan bakteri patogen tergantung kualitas air baku.

Penelitian ini dilakukan di bantaran Sungai Mandar Kabupaten Polewali Mandar, Provinsi Sulawesi Barat dan pemeriksaan di Laboratorium penguji balai teknik kesehatan lingkungan dan pengendalian penyakit Kelas 1 Makassar Provinsi Sulawesi Selatan pada tanggal 1516 juni 2019.

Rancangan penelitian ini dilakukan selama 6 bulan dari bulan maret sampai bulan agustus 2019 melalui observasi untuk mendapatkan data dan informasi terkait dengan objek dan lokasi penelitian berupa data primer, penelitian kepustakaan dan hasil uji laboratorium.

Jenis penelitian yang digunakan adalah eksperimen semua (quasy experimental). Maksud dari penelitian ini adalah untuk menganalisis jumalh bakteri total coliform yang terdapat ada wai sauq 
Adapun skema disain pelaksanaan penelitian ini adalah sebagai berikut:

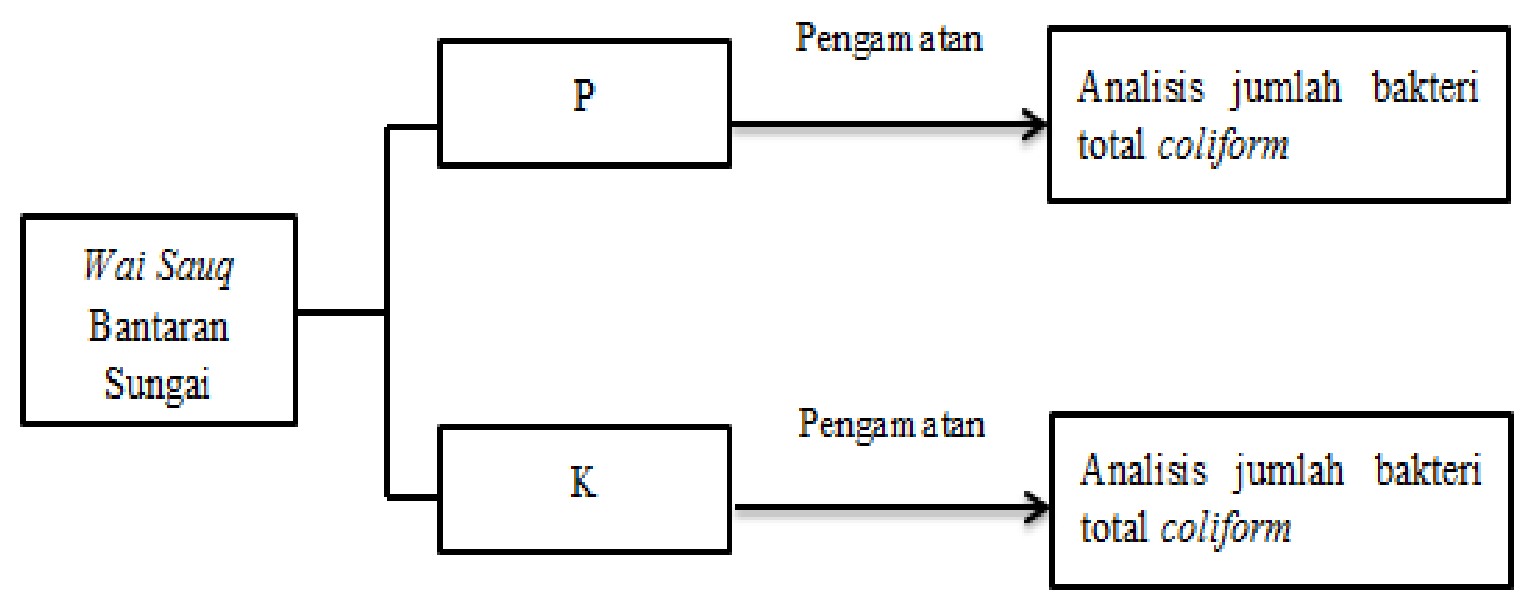

Keterangan:

$\mathrm{P}$ : kelompok perlakuan pemberian dosis chlorin $3 \mathrm{mg} / \mathrm{l} .3,5 \mathrm{mg} / \mathrm{l} \mathrm{dan} 4 \mathrm{mg} / \mathrm{l}$

$\mathrm{K}$ : Kelompok kontrol yang diberi perlakuan menggunakan dosis standar menurut word health organitation yaitu kandungan klorin $2,5 \mathrm{mg} / \mathrm{l}$

Teknik pengmpulan data dilakukan memperoleh data sekunder dan setelah dengan metode observasi oleh tim peneliti pengambilan sampel dilakukan langkah untuk mendapatkan data dan informasi terakhir adalah melakukan uji laboratorium berkaitan dengan objek penelitian dan wai sauq di balai teknik kesehatan lokasi penelitian berupa data primer serta lingkungan dan pengendalian penyakit penentuan titil lokasi pengambilan sampel Kelas 1 Makassar. wai sauq, selanjutnya kepustakaan untuk 
Berikut adalah penjelsan mengenai tahapan pelaksanaan peneliitian

Gambar 2: Tahapan Penelitian

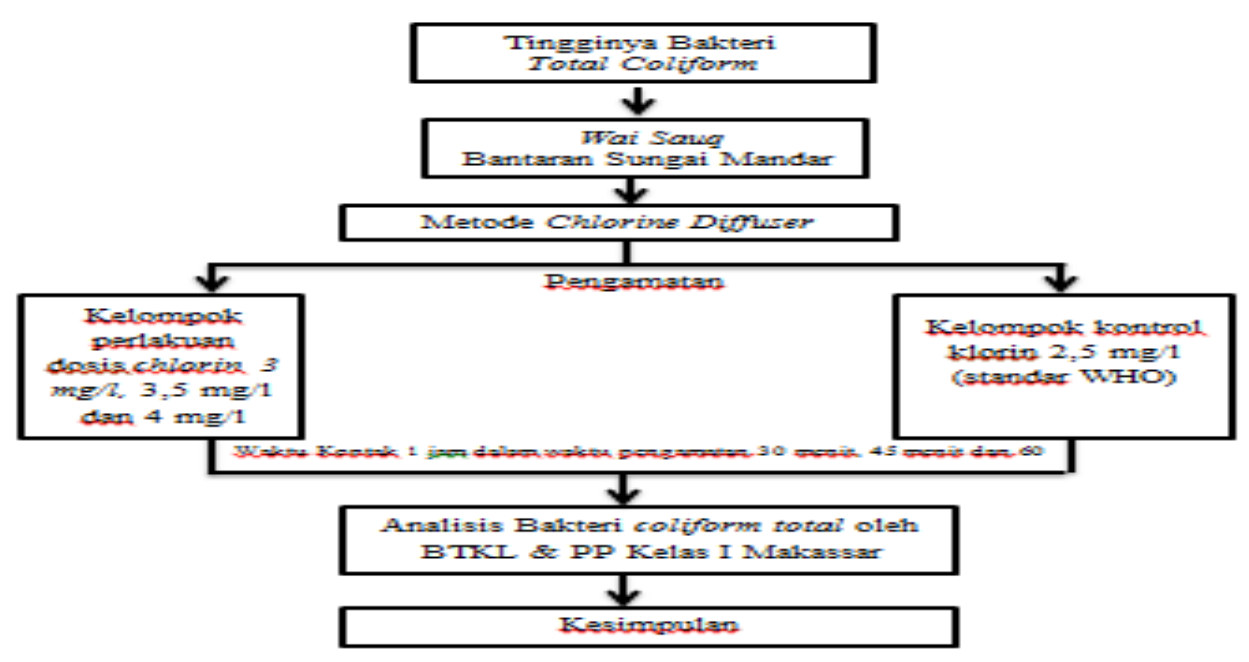

Tahapan penelitin yang dirancang mengacu pada peraturan Menteri Kesehatan RI Nomor: 907/menkes/Per/VII/2002 tentang syarat-syarat dan pengawasan kualitas air dan Peraturan menteri kesehatan RI nomor: 416/Menkes/Per/IX/1990 tentang syarat-syarat dan pengawasan kualitas air.

Dalam penelitian ini dilakukan analisis jumlah bakteri total coliform pada kelompok kontrol berdasarkan standar word health organitation yaitu untuk kandungan klorin 2,5 mg/l dan pada kelompok perlakuan pemberian dosis klorin $3 \mathrm{mg} / \mathrm{l}, \quad 3,5 \mathrm{mg} / \mathrm{l}$ dan $4 \mathrm{mg} / \mathrm{l}$.

\section{Hasil dan Pembahasan}

\section{(1) Analisis total coliform wai sauq bantaran Sungai Mandar}

Total coliform termasuk bakteri yang dapat ditemukan di lingkungan tanah dan air yang tel;ah terpengaruh oleh air
Selanjutnya hasil perlakuan di observasi dengan melakukan pengamatan dan perhitungan jumlah bakteri total coliform berdasarkan dosis dan aplikasi waktu pengamatan selama kontak 1 jam yaitu rentang antara waktu 30 menit, 45 menit dan 60 menit.

permukaan serta limbah pembuangan kotoran manusia dan hewan. Pelaksanaan penelitian pada penerapan dosis sampel awal berupa analisa kandungan bakteri total coliform berdasarkan standar Word Health Organitation maka hasil analisis jumlah bakteri pada wai sauq pada 
bantaran Sungai Mandar pada kelompok kontrol berdasarkan standar word health organitation pada aplikasi waktu pemantauan 30, 45 dan 60 menir atau sebelum diberikan perlakuan dosis klorin $2,5 \mathrm{mg} / \mathrm{l}$ di sajikan pada tabel 2 .

Tabel 2. Hasil analsisi total coliform kelompok kontrol pada wai sauq bantaran Sungai Mandar

\begin{tabular}{llcccc}
\hline No & Parameter & Satuan & $\begin{array}{c}\text { Dosis Klorin } \\
(\mathrm{mg} / \mathrm{l})\end{array}$ & $\begin{array}{c}\text { Waktu } \\
\text { pemantauan } \\
(\mathrm{menit})\end{array}$ & $\begin{array}{c}\text { Hasil } \\
\text { Pengujian }\end{array}$ \\
\hline \multirow{2}{*}{$\begin{array}{l}\text { Total } \\
\text { coliform }\end{array}$} & Jumlah per 100 & 2,5 & 30 Menit & $>1600$ \\
& & & 45 menit & 350 \\
& & & 60 menit & 220 \\
\hline
\end{tabular}

Total coliform yang terdapat dalam air apabila melebihi ambang batas standar baku mutu maka tidak layak digunakan untuk pemeliharaan kebersihan diri, keperluan mencuci bahan pangan, dan air minum. Sesuai dengan Peraturan menteri kesehatan nomor 32 tahun 2017 untuk media air keperluan higiene sanitasi adalah total coliform 50/100ml sampel.
Hasil analisis sampel wai sauq bantaran Sungai Mandar yang pada perlakuan dosis klorin $3 \mathrm{mg} / \mathrm{l}, 3,5 \mathrm{mg} / \mathrm{l}$ dan $4 \mathrm{mg} / \mathrm{l}$ pada aplikasi pengamatan dan perhitungan bakteri total coliform berdasarkan dosis aplikasi waktu pengamatan selama kontak 1 jam dalam waktu pengamatan rentang antara waktu 30 menit, 45 menit dan 60 menit yang di jabarkan pada tabel berikut ini: 
DOI: http://dx.doi.org/10.35329/jkesmas.v5i2

Tabel 4. Hasil analsii total coliform pada kelompok perlakuan wai sauq

\begin{tabular}{|c|c|c|c|c|}
\hline Parameter & Satuan & $\begin{array}{c}\text { Dosis Klorin } \\
(\mathrm{mg} / \mathrm{l})\end{array}$ & $\begin{array}{c}\text { Waktu } \\
\text { pemantauan } \\
\text { (menit) }\end{array}$ & Hasil Pengujian \\
\hline \multirow{9}{*}{$\begin{array}{l}\text { Total } \\
\text { coliform }\end{array}$} & \multirow{9}{*}{$\begin{array}{c}\text { Jumlah per } 100 \\
\text { ml sampel }\end{array}$} & \multirow[t]{3}{*}{3} & 30 Menit & $>1600$ \\
\hline & & & 45 menit & 240 \\
\hline & & & 60 menit & 280 \\
\hline & & \multirow[t]{4}{*}{3,5} & 30 Menit & $>1600$ \\
\hline & & & 45 menit & 920 \\
\hline & & & 60 menit & 46 \\
\hline & & & 30 Menit & 1600 \\
\hline & & \multirow[t]{2}{*}{4} & 45 menit & 220 \\
\hline & & & 60 menit & 46 \\
\hline
\end{tabular}

Kualitas Wai Sauq Bantaran Sungai Mandar berdasarkan jumlah bakteri total coliform dibandingkan dengan peraturan menteri kesehatan nomor 32 tahun 2017

Peraturan menteri kesehatan tentang standar baku mutu kesehatan lingkungan dan persyaratan kesehatan air untukkeperluan higiene sanitasi, kolam renang, solus per aqua dan permandian umum menjelaskan bahwa standar baku mutu kesehatan lingkungan adalah spesifikasi teknis atau nilai yang dibakukan pada media lingkungan yang berhubungan atau berdampak langsung terhadap kesehatan masyarakat.
Air merupakan salah satu media lingkungan yang harus ditetapkan Standar baku Mutu Kesehatan Lingkungan dan Persyaratan Kesehatan. Akibat perkembangan lingkungan menyebabkan berkurangnya ketersediaan air bersih untuk keperlua higiene sanitasi. Hasil pengujian sampel wai sauq menunjukkan kualitas air yang ditunjukan pada tabel berikut:

Tabel 3. Standar baku mutu kesehatan lingkungan dan persyaratan kesehatan air

\begin{tabular}{cccc}
\hline No & Parameter & Unit & $\begin{array}{c}\text { Standar Baku Mutu } \\
\text { (kadar maksimum }\end{array}$ \\
\hline 1 & Total coliform & CFU/100ml & 50 \\
2 & E. coli & CFU/100ml & 0 \\
\hline
\end{tabular}




\section{Pembahasan}

Air adalah media lingkungan yang wajib di atur mengani standar baku mutu kesehatan lingkungan dan persyaratan kesehatannya. Standar baku mutu yang dibituhkan higiene sanitasi meliputi fisik, biologi dan kimia baik berupa parameter wajib dan tambahan.

Parameter wajib merupakan parameter yang harus diperiksa secara berkala sesuai dengan peraturan yang berlaku sedangkan parameter tambahan hanya diwajibkan untuk diperiksa jika kondisi mengidentifikasi adanya pencemaran yang terjadi ${ }^{(16)}$. sebagaimana yang tercantum dalam Peraturan Menteri Kesehatan No.32 tahun 2017 tentang standar baku mutu lingkungan dan persyaratan air untuk keperluan higiene sanitasi, kolam renang, solus per aqua dan permandian umum. ${ }^{(17)}$.

Standar baku mutu kesehatan lingkungan media air untuk keperluan higiene sanitasi digunakan untuk pemeliharaan kebersihan perorangan yang meliputi parameter wajib dan parameter tambahan yang harus diperiksa secara berkala sesuai dengan ketentuan perundang-undangan.

Sungai Mandar sejatinya adalah batang air yang mengalir melewati ratusan pemukiman dan telah mengalami penurunan kualitas air. Hasil analisis terhadap data wawancara yang dikumpulkan baik dari pihak Pemerintah Kecamatan dan Masyarakat biasa yang bermukim di bantaran Sungai Mandar menunjukan bahwa pemanfaatan wai sauq tersebut adalah untuk sumber air minum, masak (tanpa melalui proses pengolahan terlebih dahulu), sanitasi, mandi, mencuci dan membersihkan hewan ternak.

Meski hampir semua rumah mempunya sumber air, baik berupa saluran pipa dari sugai ataupun sumur tanah, bisa dikatakan sebagian besar masyarakat mengandalkan air sungai wai sauq sebagai sumber untuk air minum dan memasak bahan ada yang lebih suka meminum air Sungai Mandar dari pada air gallon yang banyak dijual dan sebagian orang Mandar bahwa air sungai dipercaya memiliki khasiat sebagai obat. ${ }^{(13)}$.

Keberadaan bakteri di air permukaan melebihi ambang batas. Salah satu pencemaran secara mikrobiologis yang terjadi di perairan yaitu melimpahnya bakteri coliform yang termasuk dalam golongan bakteri intestinal, yang hidup dalam saluran pencernaan manusia. Kasus diare di Kecamatan Limboro masih cukup 
tinggi, yaitu 102 kasus (16\%) dari laporan tingkat kejadian 10 penyakit terbesar.(limboro) Untuk itu sebagai ulpaya pencegaha terhadap pedia utama terjadinya penularan penyakit, perlu dilakukan suatu kontrol kualitas air dengan perlakuan yang tepat dan berhasil guna. Curah hujan yang lebat dan terjadinya banjir memperburuk sistem sanitasi yang belum memadai, sehingga masyarakat rawan terkena penyakit menular melalui air eperti diare dan lain-lain. Di tinjau dari kesehatan masyarakat, kebutuhan air untuk keperluan higienen sanitasi harus memenuhi syarat kualitas agar kesehatan masyarakat terjamin (permenkes 2017). Apabila penyakit yang ditularkan melalui air bisa ditekan keberadaannya maka beban yang ditanggung oleh masyarakat bisa diturunkan melalui kegiatan penyehatan air ${ }^{(14)}$.

Berdasarkan Peraturan menteri kesehatan RI nomor 416 tahun 1990 tentang syarat-syarat dan pengawasan kualitas air bersih menyebutkan bahwa kandungan bakteri total coliform dalam air bersih yaitu 50/100 $\mathrm{ml}$ air perpipaan, dan 10/100 ml untuk air non perpipaan (peremenkes 416,1990). dan peraturan menteri kesehatan nomor 492 tahun 2010 tentang persyaratan kualitas iar minum menyebutkan bahwa kandungan bakteri eschercia coli dalam air minum yaitu 0/100 ml. oleh sebab itu, air bersih dan air minum tidak boleh melebihi persyaratan yang telah ditentukan ${ }^{(5)}$.

Tingginya pencemaran antara lain disebabkan oleh sistem sanitasi di lingkungan masyarakat yang masih buruk. Semakin tinggi tingkat kontaminasi bakteri coliform, semakin tinggi pula resiko kehadiran bakteri-bakteri patogen lain yang biasa hidup dalam kotoran manusia dan hewan yang dapat menyebabkan diare, kram perut, mual, rasa tidak enak badan dan kanker.

Hasil pantauan oleh Dinas Lingkungan Hidup dan Kehutanan Kabupaten Polewali Mandar untuk parameter total coliform pada lokasi sampel air permukaan wai sauq bantaran Sungai Mandar pada tahun 2018 yaitu 920 koloni/100 ml dan hasil pemeriksaan yng dilakukan pada tahun 2019 mencapai angka 1.600 koloni/100ml, hal ini menunjukkan bahwa wai sauq mengandung total coliform yang tidak memenuhi syarat batas maksimum, berdasarkan Peraturan menteri kesehatan 32 tahun 2017.

Penggunaan metode chlorine diffuser pada proses pengolahan air dengan 
tujuan membunuh kuman atau bakteri patogen, selain itu metode ini juga digunakan dalam mencegah dan mengurangi tingkat pencemaran bakteri total coliform dengan menggunakan kaporit, karena proses clorinasi mudah diaplikasikan, murah dan dapat dilakukan penggantian ulang.

Klorin merupakan desinfektan yang paling banyak digunakan pada pengolahan air minum karena efektif pada konsentrasi rendah, murah dan membentuk residual jika digunakan pada dosis yang tepat. Penggunaan klorida untuk membunuh bakteri dalam air sebagai proses desinfeksi dan kemampuannya sebagai oksidator kuat yang sangat berguna bagi kesehatan manusia..

Menurut survey teraru, 63 juta orang di India tidak memilikii atau kekurangan akses ai minum yan gaman. Hasil penelitian mengulas tentang klroin yang digunakan sebagai desinfektan sebagai teknologi klorinasi untuk air permukaan $^{(17)}$

Setelah dilakukan penambahan klorin pada sampel wai sauq dengan aplikasi waktu 1 jam maka tingkat penurunan kandungan bakteri total coliform memenuhi standar baku kadar maksimum yang dipersyaratkan yaitu 50/100ml. penerapan clorine diffuser dengan menambahkan klorin dilakukan sampai mendapatkan dosis optimum dalam menurunkan bakteri yaitu $3,5 \mathrm{mh} / \mathrm{l}$ sampai dosis $4 \mathrm{mg} / \mathrm{l}$ dengan aplikasi waktu antara 30 menit sampai dengan 60 menit pemantauan.

Dosis optimum penambahan klorin pada penggunaan metode chlorine diffuser wai sauq bantaran Sungai Mandar adalah dosis 3,5 mg/l dan $4 \mathrm{mg} / \mathrm{l}$ menunjukkan hasil yang sama berdasarkan aplikasi waktu pemantauan selama 60 menit yaitu sebesar 46 koloni/100 $\mathrm{ml}$ sampel. (BTKLPP)

Penelitian terkait penerapan teknologi buffer stock alat chlorine diffuser untuk Sdk/Klb Di Balai Teknik Kesehatan Lingkungan Dan Pengendalian Penyakitpp Yogyakarta

\section{KESIMPULAN}

Dengan merujuk Standar baku mutu kesehatan lingkungan dan persyaratan kesehatan air pada penggunaan metode chlorine diffuser penambahan klorin sampai pada dosis optimum yaitu $4 \mathrm{mg} / \mathrm{l}$ dengan aplikasi waktu 30 sampai dengan 60 menit berdasarakan hasil pemantauan mampu 
menurunkan jumlah bakteri total coliform pada wai sauq bantaran Sungai Mandar.

Penerapan alat chlorine diffuser pada proses air bersih dapat menjadi salah satu solusi yang efektif untuk diterapkan di masyarakat khususnya yang memanfaatkan wai sauq sebagai sumber air minum. didapatkan hasil monitoring yang dilakukan menunjukkan penurunan parameter Total coliform dan E.Coli sebelum dan sesudah pemasangan alat chlorine diffuser, karena hasil laboratorium menunjukkan penurunan parameter total coliform $^{(12)}$.

\section{UCAPAN TERIMA KASIH}

Ucapan terima kasih disampaikan kepada DRPM Kementerian Riset dan Pendidikan Tinggi Republik Indonesia atas Hibah Proposal Dosen Pemula dengan Surat Perjanjian Kontrak PDP Nomor 063/L6/AK/SP2H/PENELITIAN/2019 tanggal 8 April 2019.

\section{DAFTAR RUJUKAN}

1. Permenkes RI, 2017.,Data dan Informasi Profil Kesehatan Indonesia. Jakarta. Kemenkes RI Badan Pusat Statistik Indonesia. Jakarta. 2018.
2. Alimuddin Ridwan. 2011. Mandar Nol Kilometer. Yogyakarta. Penerbit Ombak.

3. Badan Lingkungan Hidup. 2019. Laporan hasiluji permukaan wai sauq. Polewali Mandar Badan Lingkungan Hidup

4. (1990). Peraturan menteri kesehatan nomor 416. jakarta: Menteri Kesehatan.

5. (2010). Peraturan menteri kesehatan. Jakarta: Menteri kesehatan RI.

6. Bambang G.A, F. K. (2014, agustus). Analisis cemaran bakteri coliform dan identifikasi echerichia coli pada air isi ulang. jurnal ilmiah farmasi, 1-10.

7. BLH. (2019). Laporan hasil uji air permukaan wai sauq. Polewali Mandar: BLH.

8. Balai Teknik Kesehatan Lingkungan Dan Pengendalian Penyakit dan PP . (laporan hasil uji Air Permukaan Wai Sauq). 2019. Kementerian Kesehatan RI, Direktoral Jenderal Pencegahan dan Pengendalian Penyakit. makassar: 2019.

9. Kemenkes. (2017). Data dan Informasi profil Kesehatan Indonesia. Jakarta: Kemenkes RI.

10. Limboro, P. (2016). Laporan profil tahunan puskesmas. polewali mandar: puskesmas tinambung. 
11. Peraturan menteri kesehatan. (2017). standar baku mutu kesehatan lingkungan . jakarta: 2017.

12. Retaningsih J.D, D. (2014, Desember). Model/Tekonologi buffer stock chlorine diffuse untuk SDK/KLB. Human Media, 8 ( 2), 13-21.

13. Ridwan, A. (2011). Mandar Nol Kilometer. Yogyakarta: 2011.

14. Rohim, M. (2006). Analisis penerapan metode kaporitisasi sederhana terhadap kualitas bakteriologis air PMA. semarang: program pscasarjana magister kesehatan lingkungan.

15. Rohman. (2007). Kimia Farmasi Analisis. Yogyakarta: Pustaka Pelajar.
16.S inayatus, Y. (2018). Studi Kualitas mikrobiologi air sumur gali sebelum dan sesudah menggunakan chlorine diffuser desa selabaya kecamatan kalimanah. jurnlal esehatan lingkungan politeknik kesehatan kemenkes semarang, 1-8.

17. T.Vijaya Prasadini, N. M. (2019). The Future of Chlorine Disinfectant Choice in Rural Areas. International Journal of Innovative Technology and Exploring Engineering (IJITEE, 1-5.

18. Usna Juwita, Y. H. (2014). Jumlah bakteri coliform dan deteksi Escherichia coli. JOM FMIPA, 48-55. 